\title{
EFFECT OF PRESS TEMPERATURE ON SOME PROPERTIES OF CEMENT BONDED PARTICLEBOARD
}

\author{
Husnu Yel, , Ayfer Donmez Cavdar', Sevda Boran Torun ${ }^{3}$
}

\begin{abstract}
It is known that there is a correlation between hydration heat and physico-mechanical properties of wood based cement panels. Cement hydration is affected by many variables, such as chemical composition, water/ cement ratio, wood/cement ratio, wood chemical properties, mineral additions and producing conditions. This study mainly aimed to investigate the effects of press temperature on some properties of three-layer cement bonded particleboard made from the particles of spruce (Picea orientalis) and poplar (Populus tremula). For this purpose, a total of 16 experimental board groups with $1200 \mathrm{~kg} / \mathrm{m}^{3}$ target density and $1 / 3$ wood-cement ratio were produced at the press temperatures of $(20,30,40,50,60,70$ and 80$){ }^{\circ} \mathrm{C}$. As cement curing accelerator, $\mathrm{CaCl}_{2}$ was used at a rate of $5 \%$ (cement weight basis). The physical, mechanical and thermal properties of the boards were determined. The results indicated that the press temperature substantially affected the properties of cement-bonded particleboard depending on the wood species. In the light of this study, the optimum temperatures in producing of cement-bonded particleboard were found as $40{ }^{\circ} \mathrm{C}$ for poplar wood and $60{ }^{\circ} \mathrm{C}$ for spruce wood.
\end{abstract}

Keywords: Mechanical properties, physical properties, Picea orientalis, Populus tremula, thermal properties.

\section{INTRODUCTION}

Wood based cement panels have been rapidly accepted in the construction industry due to their perfect exterior properties (Maail et al. 2011). These panels have been recently preferred for exterior walls, external cladding, protective elements for fireproofing, roof shingles, tiles, specialized flooring and sound insulation etc. The major advantages of the panels are their good acoustical and thermal insulating properties and high performance to resist decay, fungi, insects, moisture, fire (Fan et al. 2004, Tabarsa and Ashori 2011, Yel et al. 2011, Tittelein et al. 2012, Yel et al. 2017). According to the morphology of the wood particles used in the panel manufacture, wood cement panels are named wood wool cement boards, cement bonded fiberboard, cement bonded particleboard, and wood strand cement boards, respectively (Jorge et al. 2004, Kalaycioglu et al. 2012, Donmez Cavdar et al. 2017, Yel et al. 2017).

The compatibility indicates cement-curing degree after mixing with water and wood particle/fiber and significantly affects the strength properties of wood cement composites. Therefore, the compatibility between wood and cement is very important. The presence of wood is the most important factor because of its water-soluble extractive compounds, which can inhibit cement curing. Polysaccharides in wood extractives prevent the forming of the main hydrates $\left(\mathrm{Ca}(\mathrm{OH})_{2}\right.$ and $\left.\mathrm{C}-\mathrm{S}-\mathrm{H}\right)$ of cement (Tittelein et al. 2012, Biblis and Lo 1968, Weatherwax and Tarkow 1964, Thomas and Birchall 1983). In the presence of sugar acids, sugars and

\footnotetext{
${ }^{1}$ Department of Material and Material Processing Technologies, Artvin Vocational School, Artvin Coruh University, Artvin, Turkey.

${ }^{2}$ Department of Interior Architecture, Faculty of Architecture, Karadeniz Technical University, Trabzon, Turkey.

${ }^{3}$ Department of Woodworking Industry Engineering, Faculty of Technology, Karadeniz Technical University, Trabzon, Turkey.

•Corresponding author: yel33@artvin.edu.tr

Received: 23.03.2019 Accepted: 27.11.2019
} 
lignosulfonates, cement grains are surrounded by acicular hydrates and are formed around un-hydrated cement grains, which prevent the curing of cement (Fischer et al. 1974, Sandermann and Kohler 1964). It is known that some methods such as mineral additives, $\mathrm{CO}_{2}$ injection, cold-hot water and $\mathrm{NaOH}$ extractions are applied to reduce the incompatibility between wood and cement (Jorge et al. 2004). In addition to wood species, many factors such as wood-cement ratio, cement type, water-cement ratio, manufacturing conditions, mineral additions (curing accelerator types) and their mixing ratio affect the quality of wood based cement panels.

The quality of wood-based cement panels is mostly related to the maximum hydration temperature of cement during curing. Sanderman and Kohler (1964) have reported a relationship between wood-cement compatibility and cement hydration temperature. In another study, it was also concluded that direct heat treatment during the pressing process accelerated curing of cement in wood-based cement panels (Cabangon 1997). To the best of authors' knowledge, a comprehensive research has not been done about what the temperature should be and how the optimal temperature varies according to wood species during hydration reaction of wood-cement-water mixture. Therefore, the aims of this study are to investigate the effect of the press temperature applied during pressing on the properties of cement-bonded particleboards (CBPBs), to determine the optimal press temperature for producing these boards and if the optimum temperature value has changed according to the wood species.

\section{MATERIALS AND METHODS}

Poplar (Populus tremula L.) and spruce (Picea orientalis (L.) Link.) samples were obtained from Trabzon Sozenler Forest Products Co., Turkey. The commercial ordinary Portland cement, CEM II B-M (P-LL) 32,5 R type, used as binder, was supplied by Askale Cement Co. in Turkey. Calcium chloride $\left(\mathrm{CaCl}_{2}\right)$ was bought in solid form from Merck Chemicals Ltd.

Sawmill residues were firstly chipped in a laboratory-type hammer mill and then refined into fine particles for manufacturing three-layer particleboard in a knife-ring chipping machine. Afterwards, all the particles were sieved with a vibrating horizontal screen to generate surface and core layers particles. The particles, which passed through the $3 \mathrm{~mm}$ sieve and retained on 1,5 $\mathrm{mm}$ sieve, were used for core layer, while the particles, which passed through the $1,5 \mathrm{~mm}$ sieve and retained on $0,5 \mathrm{~mm}$ sieve, were used for surface layers. The core/ surface layers ratio was 65/35 for each board group. The wood/cement ratio, based on the oven dry weight, was selected as $1 / 3$ for producing the three-layer CBPBs. Calcium chloride $\left(\mathrm{CaCl}_{2}\right)$ was used as an accelerator to reduce the incompatibility between wood and cement. The accelerator ratio was chosen according to Yel et al. (2010). They reported that optimum $\mathrm{CaCl}_{2}$ content was 5 percent based on cement weight for CBPBs. The amount of distilled water was calculated by Equation 1 below, developed by Simatupang (1979).

$$
\text { Water }(\text { liter })=0,35 C+(0,30-M C) W
$$

$$
\begin{aligned}
& \text { Where } \\
& \mathrm{C}=\text { cement weight }(\mathrm{kg}) \\
& \mathrm{MC}=\text { wood moisture content (oven dry basis) } \\
& \mathrm{W}=\text { oven-dry wood weight }(\mathrm{kg}) .
\end{aligned}
$$

The experimental design is given in Table 1. 
Table 1: Experimental design of the production of CBPBs.

\begin{tabular}{|c|c|c|c|c|c|}
\hline ID & $\begin{array}{c}\text { Wood } \\
\text { Species }\end{array}$ & $\begin{array}{c}\text { Press Temp. } \\
\left({ }^{\circ} \mathbf{C}\right)\end{array}$ & ID & $\begin{array}{c}\text { Wood } \\
\text { Species }\end{array}$ & $\begin{array}{c}\text { Press Temp. } \\
\left({ }^{\circ} \mathbf{C}\right)\end{array}$ \\
\hline P2 & Poplar & 20 & S2 & Spruce & 20 \\
\hline P3 & Poplar & 30 & S3 & Spruce & 30 \\
\hline P4 & Poplar & 40 & S4 & Spruce & 40 \\
\hline P5 & Poplar & 50 & S5 & Spruce & 50 \\
\hline P6 & Poplar & 60 & S6 & Spruce & 60 \\
\hline P7 & Poplar & 70 & S7 & Spruce & 70 \\
\hline P8 & Poplar & 80 & S8 & Spruce & 80 \\
\hline
\end{tabular}

The mixture of wood/cement/water was hand formed inside a wooden mold. Afterwards, the hand-formed panel was removed from the wooden mold and compressed in a hot press under a pressure of (18-20) $\mathrm{kg} /$ $\mathrm{cm}^{2}$ for $24 \mathrm{hrs}$. In the first $8 \mathrm{~h}$ of pressing, 8 different temperatures for each group were applied (Table 1) and then the pressing continued for $16 \mathrm{~h}$ at ambient temperature. Three replicates were made at a dimension of 45 $\mathrm{cm} \times 45 \mathrm{~cm} \times 1 \mathrm{~cm}$ and a target density of $1200 \mathrm{~kg} / \mathrm{m}^{3}$ for each board type. In order to complete the cement hydration, the boards were conditioned at $20{ }^{\circ} \mathrm{C}$ and $65 \% \mathrm{RH}$ for one month and then the test samples were prepared, based on the principles specified in the European Standards.

The density BS EN 323 (BSI 1993), moisture content ASTM D1037-12 (ASTM 2012), water absorption BS EN 322 (BSI 1993), thickness swelling BS EN 317 (BSI 1993), bending properties BS EN 310 (BSI 1993), internal bonding strength BS EN 319 (BSI 1993) and screw withdrawal strength BS EN 320 (BSI 1993) for CBPB samples were determined by the given standards. Ten samples were tested for each type of board.

TGA/DTA analyses were performed by means of a simultaneous DTA-TGA thermal analyzer apparatus (Shimadzu DTG-60, Japan) under nitrogen atmosphere at a rate of $10{ }^{\circ} \mathrm{C} / \mathrm{min}$ from (30 to 900) ${ }^{\circ} \mathrm{C}$.

Mechanical test results of all the CBPBs were evaluated statistically with One Way ANOVA and Duncan's mean separation test by using SPSS 21.0 (IBM 2018).

\section{RESULTS AND DISCUSSION}

\section{Mechanical properties}

The bending properties of the boards are given in Figure 1. Letters in Figure 1 represent Duncan's mean separation test results. According to the variance analysis test-One Way ANOVA, wood species and press temperatures affected substantially all tested mechanical properties of CBPBs (p values: $99 \%$ ).

Modulus of rupture (MOR) and modulus of elasticity (MOE) values depending on the press temperature and wood species ranged from 2,72 MPa to $11,96 \mathrm{MPa}$ and $2093 \mathrm{MPa}$ to $5627 \mathrm{MPa}$, respectively. The highest MOR and MOE values were recorded by board type of $\mathrm{P} 4$ produced with poplar particles at $40{ }^{\circ} \mathrm{C}$ press temperature while the boards produced with spruce particles at $60{ }^{\circ} \mathrm{C}$ had highest MOR and MOE values. However, over $60^{\circ} \mathrm{C}$, a sharp decrease in the bending properties of the CBPBs was observed. All the groups excluding $\mathrm{P} 7, \mathrm{P} 8, \mathrm{~S} 7$ and $\mathrm{S} 8$ produced at $70{ }^{\circ} \mathrm{C}$ and $80^{\circ} \mathrm{C}$ met the minimum MOR $(9 \mathrm{MPa}$ ) and MOE (class 1: $4500 \mathrm{MPa}$ and class 2: $4000 \mathrm{MPa}$ ) requirements stated in BS EN 634-2 (BSI 1997). It was shown that the press temperatures above $60^{\circ} \mathrm{C}$ led to a significant decrease in the MOR and MOE values of the boards made from both spruce and poplar. 


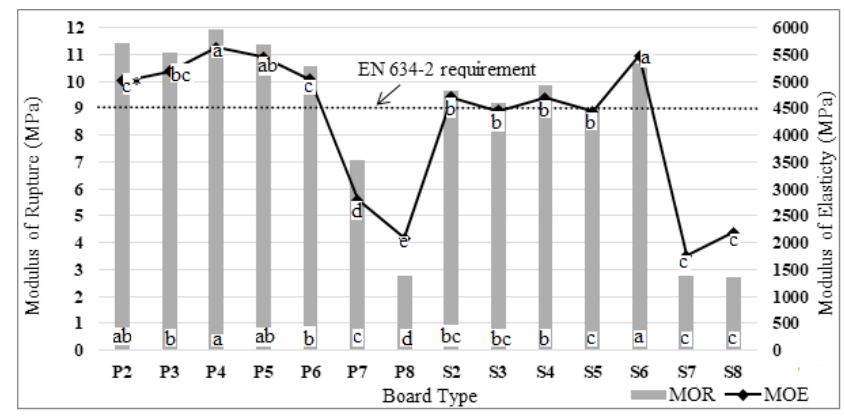

Figure 1: Effect of press temperature on the bending properties of the CBPBs.

*Groups with same letters signify that there is no statistical difference $(\mathrm{p}<0,001)$ between the board types based on Duncan's multiply range test.

The poplar boards had generally higher MOR and MOE values than the spruce boards because poplar had higher $\mathrm{pH}$ values $(6,32)$ than spruce $(5,03)$ (Yel 2015). The hydration reaction of the cement is carried out in alkaline environment $(\mathrm{pH}: 12,5)$ and wood with low $\mathrm{pH}$ value may negatively affect the cement board properties (Hachmi and Moslemi 1990). For this reason, the $\mathrm{pH}$ of poplar wood is more suitable than that of spruce wood for manufacturing cement bonded particleboards.

The wood extractives induce a complexity with the metal ions in the cement solution, causing the reduction of $\mathrm{Ca}^{2+}$ concentration in the cement, and disrupting the stability of the solution. This inhibits the formation of $\mathrm{Ca}(\mathrm{OH})_{2}$ and C-S-H gel which are hydration products of cement (Janusa et al. 2000), and leads to a significant decrease in the properties of CBPBs. This caused a decrease in MOR and MOE of the boards produced at $70{ }^{\circ} \mathrm{C}$ and $80^{\circ} \mathrm{C}$ because the amount of soluble substances, which inhibit the hydration of cement, in wood increases with an increase in press temperature and alkali environment.

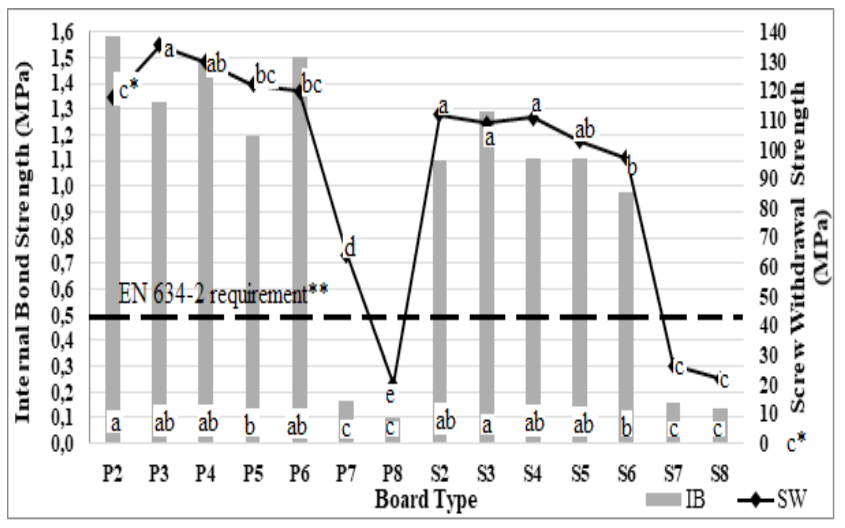

Figure 2: Effect of press temperature on internal bond (IB) and screw withdrawal (SW) strength of the CBPBs. *Groups with same letter are not statistically different $(\mathrm{p}<0,001)$ based on Duncan's multiply range test. **The standard value is only
for internal bond strength.

Figure 2 shows the results of internal bond strength (IB) and screw withdrawal strength (SW) of the CBPBs and their homogeneity groups. IB and SW values of the samples were within the range of $(0,1$ to 1,58$)$ $\mathrm{MPa}$ and (20 to 135) MPa, respectively. The highest IB values were found in the P2 group of poplar boards and 
S3 group of spruce boards, while the highest SW values were found in the P3 group of poplar boards and S2 group of spruce boards. The results were supported by other researchers. Ashori et al. (2012a) evaluated press temperatures of $25^{\circ} \mathrm{C}$ and $60^{\circ} \mathrm{C}$ on wood-based cement panels. They found that the mechanical properties of the samples decreased with an increase in the press temperature. Del Menezzi et al. (2007) and Ashori et al. (2012b) reported that the manufacturing of wood cement boards was successful when pressing at room temperature. The lowest IB and SW values were found in the groups produced at $70{ }^{\circ} \mathrm{C}$ and $80^{\circ} \mathrm{C}$. All the groups excluding the board groups (P7, P8, S7 and S8) produced at $70{ }^{\circ} \mathrm{C}$ and $80{ }^{\circ} \mathrm{C}$ met the minimum IB strength requirements $(0,5 \mathrm{MPa})$ stated in BS EN 634-2 (BSI 1997). Similar to the bending properties, the press temperatures above $60^{\circ} \mathrm{C}$ leaded to a significant decrease in the IB and SW values of the samples for both spruce and poplar.

\section{Physical properties}

The densities of the CBPBs with poplar and spruce particles were about $1210 \mathrm{~kg} / \mathrm{m}^{3}$ and $1130 \mathrm{~kg} / \mathrm{m}^{3}, \mathrm{re}-$ spectively. The samples with poplar particles had a little higher density than those of spruce particles. This may be related to density differences between the wood species. The water absorption (WA) and thickness swelling (TS) values of the cement-bonded particleboards are given in Figure 3. The WA and TS values of the samples made with spruce were higher compared to the samples produced with poplar due to differences in their density. It is known that the WA and TS rates increase with decreasing of composite density (Ashori et al. 2012a).

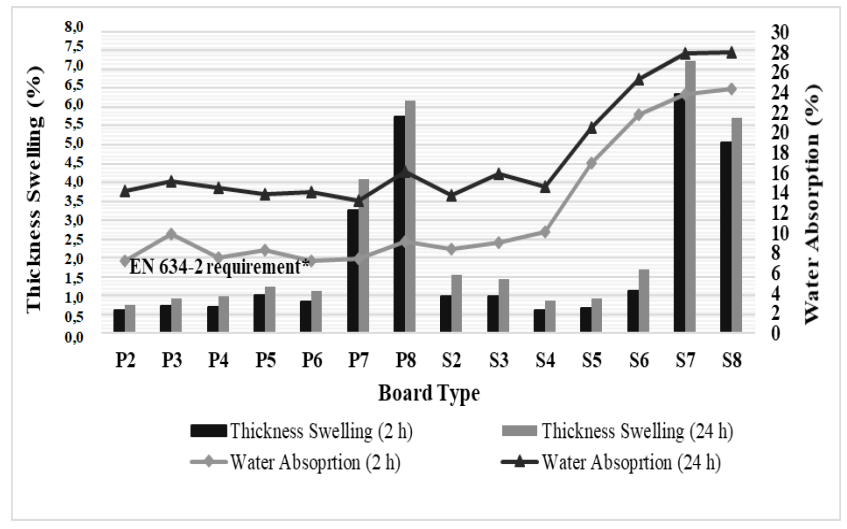

Figure 3: Water absorption and thickness swelling of the CBPBs.

*The standard value is only for thichness swelling $-24 \mathrm{~h}$.

It was observed that the press temperature had a significant adverse effect on WA and TS of the boards above $70^{\circ} \mathrm{C}$. The lowest values of WA and TS were obtained from P2 and S4 groups, while the highest values were attained from the boards produced at $70^{\circ} \mathrm{C}$ and $80^{\circ} \mathrm{C}$. It was observed that the press temperatures of up to $50^{\circ} \mathrm{C}$ led to an improvement in the WA and TS properties of the boards made of spruce particles.

The moisture contents (7 - 11) \% of all the board groups met the requirements (6 - 12) \% in BS EN 634-1 (BSI 1995). The BS EN 634-2 (BSI 1997) standard requires 1,5\% of the 24 h-maximum thickness swelling for Ordinary Portland Cement-OPC bonded particleboards. The TS values of all the board groups excluding the board groups (P7, P8, S7 and S8) produced at $70{ }^{\circ} \mathrm{C}$ and $80^{\circ} \mathrm{C}$ met the TS requirements for $24 \mathrm{~h}$ in BS EN 634-2 (BSI 1997) standard as shown in Figure 3. This indicates that the press temperature should not exceed $60{ }^{\circ} \mathrm{C}$ in producing of the cement-bonded particleboards from both poplar and spruce.

Some substances in wood, such as hemicelluloses, starches, sugars, phenols and hydroxylated carboxylic acid, inhibit the hydration of cement (Weatherwax and Tarkow 1964). The alkaline environment in wood-cement paste arises during cement hydration and may dissolve hemicelluloses (Miller and Moslemi 1991). The increase in the press temperature and alkaline environment may have caused an increase in the solubility of 
the extractive substances and hemicellulose in the wood particles, which can prevent the hydration reaction of cement. The cement could not prevent water uptake of wood particles and TS of the wood particles since the boards produced at $70{ }^{\circ} \mathrm{C}$ and $80^{\circ} \mathrm{C}$ had weak bonds in cement-wood and cement-cement (Ashori et al. 2012a).

\section{Thermogravimetric analysis (TGA/DTG)}

TGA-DTG curves of the cement-bonded particleboards made from spruce and poplar woods at different press temperatures were illustrated in Figure 4. In the figures, four endothermic peaks appeared for the cement-bonded particleboards. The first peak arose at approximately $100{ }^{\circ} \mathrm{C}$ due to the dehydration of pore water. The second peak arose at about $350{ }^{\circ} \mathrm{C}$ due to decomposition of wood components. According to Kim et al. (2006), wood components decompose at different temperatures; hemicellulose at (180 to 350$){ }^{\circ} \mathrm{C}$, cellulose at (275 to 350$){ }^{\circ} \mathrm{C}$ and lignin at $(250$ to 500$){ }^{\circ} \mathrm{C}$. The third peak arose at approximately $430{ }^{\circ} \mathrm{C}$ due to the dehydration of calcium hydroxide $\left(\mathrm{Ca}(\mathrm{OH})_{2}\right)$. The last peak arose at approximately $740{ }^{\circ} \mathrm{C}$ due to decarbonation of calcium carbonate $\left(\mathrm{CaCO}_{3}\right)$
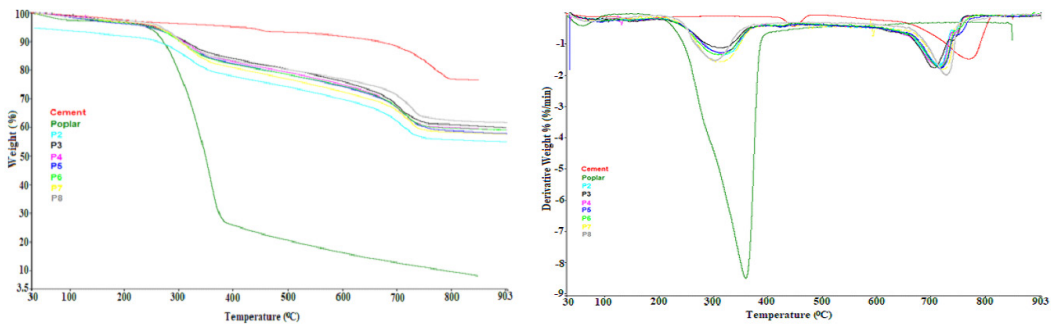

(a)
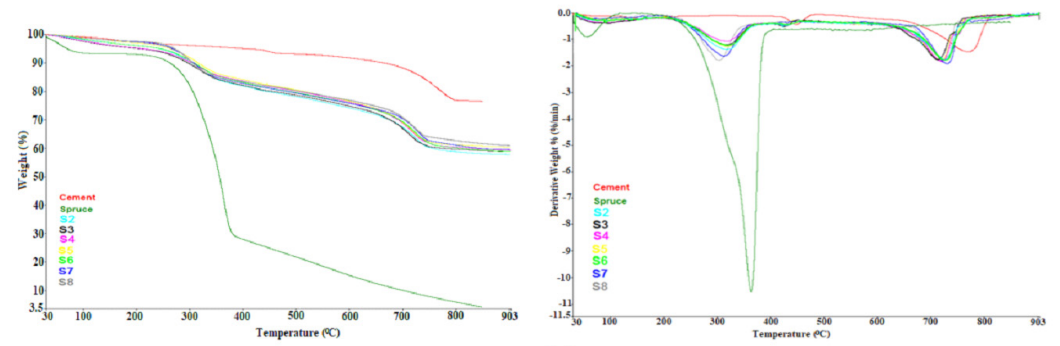

(b)

Figure 4: Thermogravimetric anlysis (TGA) / the derivative thermo-gravimetric (DTG) curves of the CBPBs produced with poplar (a) and spruce (b).

Calcium carbonate is not a hydration product as calcium hydroxide and calcium silicate hydrate. It is a result of reaction of calcium hydroxide with carbon dioxide (Shafiq and Nuruddin 2010, Cabrera and Lynsdale 1996) as shown in Equation 2.

$$
\mathrm{Ca}(\mathrm{OH})_{2}+\mathrm{CO}_{2} \rightarrow \mathrm{CaCO}_{3}+\mathrm{H}_{2} \mathrm{O}
$$

The degree of cement hydration is calculated using the amount of calcium carbonate and calcium hydroxide detected in the TGA/DTG output (Cabrera and Lynsdale 1996). The calcium hydroxide and calcium carbonate decompose at (420 to 550$)^{\circ} \mathrm{C}$ and $(600$ to 800$){ }^{\circ} \mathrm{C}$ as following Equation 3 and Equation 4, respectively (Shafiq and Nuruddin 2010, Cabrera and Lynsdale 1996). 


$$
\mathrm{Ca}(\mathrm{OH})_{2} \rightarrow \mathrm{CaO}+\mathrm{H}_{2} \mathrm{O}
$$

$$
\mathrm{CaCO}_{3} \rightarrow \mathrm{CaO}+\mathrm{CO}_{2}
$$

The weight losses of CBPB at four different temperature ranges were summarized in Table 2. The results indicate that the carbon dioxide reacted with calcium hydroxide to produce calcium carbonate $\left(\mathrm{CaCO}_{3}\right)$. The least weight losses at (420 to 550) ${ }^{\circ} \mathrm{C}$ and $(600$ to 800$){ }^{\circ} \mathrm{C}$ were obtained from the board groups (P8 and S8) produced at a press temperature of $80^{\circ} \mathrm{C}$. This may be due to the fact that the wood extractives, which are more soluble at high temperatures, inhibits cement hydration. The physical and mechanical properties of the boards are compatible with the values mentioned above. It was shown that the press temperature under $60{ }^{\circ} \mathrm{C}$ improved the hydration of cement and the properties of the cement-bonded particleboards made from both spruce particles and poplar particles.

\begin{tabular}{|c|c|c|c|c|c|c|c|c|c|}
\hline \multirow[b]{2}{*}{ ID } & \multicolumn{4}{|c|}{$\begin{array}{c}\text { Weight loss }(\%) \text { at the temperature } \\
\text { ranges }\left({ }^{\circ} \mathrm{C}\right)\end{array}$} & \multirow[b]{2}{*}{ ID } & \multicolumn{4}{|c|}{$\begin{array}{c}\text { Weight loss }(\%) \text { at the temperature } \\
\text { ranges }\left({ }^{\circ} \mathrm{C}\right)\end{array}$} \\
\hline & $0-180$ & $180-400$ & $420-550$ & $600-800$ & & $0-180$ & $180-400$ & $420-550$ & $600-800$ \\
\hline $\mathrm{P} 2$ & 2,45 & 14,31 & 5,80 & 14,05 & S2 & 3,37 & 14,61 & 5,61 & 15,41 \\
\hline P3 & 2,85 &, 06 & 76 & 14,97 & S3 & 4,31 & 13,35 & 5,31 & 15,15 \\
\hline $\mathrm{P} 4$ & 2,87 & 14,16 & 5,77 & 14,98 & S4 & 4,14 & 11,96 & 5,43 & 15,78 \\
\hline P5 & 3,37 & 14,12 & 5,90 & & S5 & 2,61 & 13,18 & 5,5 & 15,31 \\
\hline P6 & 3,13 & 14,66 & 5,52 & 14,76 & 56 & 3,37 & 13,33 & 5,4 & 15,67 \\
\hline P7 & 2,7 & 14,21 & 5,1 & & 57 & 2,2 & 14,80 & 5,1 & 14 , \\
\hline P8 & 2,55 & 14,01 & 4,74 & 14,01 & S8 & 2,14 & 14,31 & 4,90 & 14,01 \\
\hline
\end{tabular}

Table 2: Weight losses of the CBPBs at four different temperature ranges.

\section{CONCLUSIONS}

The study investigated the effect of press temperature on some properties of cement-bonded particleboard produced with spruce and poplar wood species. It was observed that press temperature applied during the hydration reaction of cement had a significant effect on physical and mechanical properties of cement bonded particleboards and this effect varied according to wood species. The optimal press temperature was $40{ }^{\circ} \mathrm{C}$ for the boards from poplar wood and $60{ }^{\circ} \mathrm{C}$ for the board produced from spruce to achieve the best physical and mechanical properties. In the light of obtained results, the press temperature should not exceed $60^{\circ} \mathrm{C}$ because it caused serious declines in the properties of cement-bonded particleboards.

\section{ACKNOWLEDGMENTS}

The authors gratefully thank Sozenler Forest Products and Yilmazlar Sawmill Companies for supplying poplar and spruce woods. 


\section{REFERENCES}

Ashori, A.; Tabarsa, T.; Amosi, F. 2012a. Evaluation of using waste timber railway sleepers in wood-cement composite materials. Constr Build Mater 27(1): 126-129. https://doi.org/10.1016/j.conbuildmat.2011.08.016.

Ashori, A.; Tabarsa, T.; Sepahvand, S. 2012b. Cement-bonded composite boards made from poplar strands. Constr Build Mater 26(1): 131-134. https://doi.org/10.1016/j.conbuildmat.2011.06.001.

ASTM. 2012. ASTM D1037-12: Standard test method for evaluating properties of wood-base fiber and particle panel materials. ASTM International, West Conshohocken, PA, USA. https://www.astm.org/Standards/D1037.htm.

Biblis, E.J.; Lo, C.F. 1968. Sugars and other wood extractives: effect on the setting of southern pine cement mixture. Forest Prod J 18(8): 28-34.

BSI. 1993. BS EN 310: Wood-based panels. Determination of modulus of elasticity in bending and bending strength. BSI, London, UK. https://shop.bsigroup.com/ProductDetail/?pid=000000000000299457.

BSI. 1993. BS EN 317: Particleboards and fibreboards-determination of swelling in thickness after immersion in water. BSI, London, UK. https://shop.bsigroup.com/ProductDetail/?pid=000000000000299500.

BSI. 1993. BS EN 319: Particleboards and fiberboards, determination of tensile strength perpendicular to plane of the board. BSI, London, UK. https://shop.bsigroup.com/ProductDetail?pid=000000000000299524.

BSI. 1993. BS EN 322: Wood-based panels. Determination of moisture content. BSI, London, UK. https:// shop.bsigroup.com/ProductDetail/?pid=000000000000299551.

BSI. 1993. BS EN 323: Wood-based panels, Determination of density. BSI, London, UK. https://shop. bsigroup.com/ProductDetail/?pid=000000000000299563.

BSI. 1995. BS EN 634-1: Cement-bonded particleboards. Specifications - part 1: general requirements. BSI, London, UK. https://shop.bsigroup.com/ProductDetail/?pid=000000000000611493.

BSI. 1997. BS EN 634-2: Cement-bonded particleboards. Specifications - part 2: Requirements for OPC bonded particleboards for use in dry, humid and external conditions. BSI, London, UK. https://shop.bsigroup. com/ProductDetail/?pid=000000000000934407.

BSI. 1993. BS EN 320: Particleboards and fibreboards - determination of resistance to axial withdrawal of screws. BSI, London, UK. https://standards.globalspec.com/std/1389134/BS\%20EN\%20320.

Cabangon, R.J. 1997. Rapid curing of wood wool cement boards from yemane (Gmelina arborea R.Br.) by direct heat application during pressing. M.S. Thesis. University of the Philippines, Los Baños, Laguna, Philippines.

Cabrera, J.G.; Lynsdale, C.J. 1996. The effect of super-plasticisers on the hydration of normal Portland cement (in Italian). L'industria Italiana del Cemento 66(712): 532-541.

Del Menezzi, C.H.S.; Gomez de Castro, V.; Rabelo de Souza, M. 2007. Production and properties of a medium density wood-cement boards produced with oriented strands and silica fume. Maderas-Cienc Tecnol 9(2): 105-115. http://dx.doi.org/10.4067/S0718-221X2007000200001.

Donmez Cavdar, A.; Yel, H.; Boran, S.; Pesman, E. 2017. Cement type composite panels manufactured using paper mill sludge as filler. Constr Build Mater 142: 410-416. https://doi.org/10.1016/j.conbuildmat.2017.03.099.

Fan, M.Z.; Bonfield, P.W.; Dinwoodie, J.M.; Boxall, J.; Breese, M.C. 2004. Dimensional instability of cement-bonded particleboard: The effect of surface coating. Cement Concrete Res 34(7): 1189-1197. https:// doi.org/10.1016/j.cemconres.2003.12.010. 
Fischer, F.; Wienhaus, O.; Ryssel, M.; Olbrech, J. 1974. Die wasserlöslichen kohlenhydrate des holzes und ihr einfluss auf die herstellung von holzwolle-leichtauplatten. Holztechnologie 15(1): 12-19.

Hachmi, M.H.; Moslemi, A.A. 1990. Effect of wood pH and buffering capacity on wood cement compatibility. Holzforschung 44(6): 425-430. https://doi.org/10.1515/hfsg.1990.44.6.425.

IBM SPSS Statistics. 2018. SPSS Statistics V21.0. IBM. New York, USA. URL: https://www.ibm.com/ support/pages/release-notes-ibm-spss-statistics-210.

Janusa, M.A.; Champagne, C.A.; Fanguy, J.C.; Heard, G.E.; Laine, P.L.; Landry, A.A. 2000. Solidification/stabilization of lead with the aid of bagasse as an additive to Portland cement. Microchem J 65(3): 255-259. https://doi.org/10.1016/S0026-265X(00)00120-X.

Jorge, F.C.; Pereira, C.; Ferreira, J.M.F. 2004. Wood-cement composites: A review. Holz Roh Werkst 62(5): 370-377. https://doi.org/10.1007/s00107-004-0501-2.

Kalaycioglu, H.; Yel, H.; Donmez Cavdar, A. 2012. Wood wool cement boards and its applications (in Turkish). Kastamonu Univ Orman Fak Derg 12(1): 122-133. https://dergipark.org.tr/tr/download/article-file/159615.

Kim, H.S.; Kim, S.; Kim, H.J.; Yang, H.S. 2006. Thermal properties of bio-flour-filled polyoefin composites with different compatibilizing agent type and content. Thermochim Acta 451(1-2): 181-188. https://doi. org/10.1016/j.tca.2006.09.013.

Maail, R.S.; Umemura, K.; Aizawa, H.; Kawai, S. 2011. Curing and degradation processes of cement-bonded particleboard by supercritical $\mathrm{CO}_{2}$ treatment. J Wood Sci 57(4): 302-307. https://doi.org/10.1007/ s10086-011-1179-9.

Miller, D.P.; Moslemi, A.A. 1991. Wood-cement composites: effect of model compounds on hydration characteristics and tensile strength. Wood Fiber Sci 23(4): 472-482. https://wfs.swst.org/index.php/wfs/article/ view/2119.

Sandermann, W.; Kohler, R. 1964. Über eine kurze eignungsprüfung von hölzern für zementgebundene werkstoffe. Holzforschung 18(1-2): 53-59. https://doi.org/10.1515/hfsg.1964.18.1-2.53.

Shafiq, N.; Nuruddin, M.F. 2010. Degree of hydration of OPC and OPC/FA pastes dried in different relative humidity. J Concr Res Lett 1(3): 81-89. https://pdfs.semanticscholar.org/be 70/a3b11316fec3751f3d9d298e5d35001ebcb5.pdf?_ga=2.41600235.856399216.1574850643-1886985546.1572353688.

Simatupang, M.H. 1979. Water requirement for the production of cement-bonded particleboard. Eur $J$ Wood Wood Prod 37(10): 379-382. https://doi.org/10.1007/BF02610947.

Tabarsa, T.; Ashori, A. 2011. Dimensional stability and water uptake properties of cement-bonded wood composite. J Polym Environ 19(2): 518-521. https://doi.org/10.1007/s10924-011-0295-3.

Thomas, N.L.; Birchall, J.D. 1983. Retarding action of sugars on cement hydration. Cement Concrete Res 13(6): 830-842. https://doi.org/10.1016/0008-8846(83)90084-4.

Tittelein, P.; Cloutier, A.; Bissonnette, B. 2012. Design of a low-density wood-cement particleboard for interior wall finish. Cement Concrete Comp 34(2): 218-222. https://doi.org/10.1016/j.cemconcomp.2011.09.020.

Weatherwax, R.C.; Tarkow, H. 1964. Effect of wood on setting of Portland cement. Forest Prod $J$ 14(12): 567-570.

Yel, H.; Kalaycioglu, H.; Donmez Cavdar A.; Oran, B. 2010. Effects of $\mathrm{Al}_{2}\left(\mathrm{SO}_{4}\right)_{3}$ and $\mathrm{Na}_{2} \mathrm{SiO}_{3}$ on some physical and mechanical properties of cement-bonded oriented strand boards with hybrid aspen (populus euroamericana cv.) strands., In: The 1st International Symposium on Turkish \& Japanese Environment and Forestry. Vol 2: 665-677. Trabzon, Turkey.

Yel, H.; Donmez Cavdar, A.; Kalaycioglu, H. 2011. Mechanical and physical properties of cement-bonded particleboard made from tea residues and hardboards. Key Eng Mater 471-472: 572-577. https://doi. 
org/10.4028/www.scientific.net/KEM.471-472.572.

Yel, H. 2015. Effects of some manufacturing factors on the properties of cement bonded particleboards. $\mathrm{PhD}$. Dissertation. Karadeniz Technical University, Trabzon, Turkey.

Yel, H.; Kalaycioglu, H.; Aras, U. 2017. Utilization of silica fume in manufacturing of cement bonded particleboards. Pro Ligno 13(4): 257-263. http://www.proligno.ro/ro/articles/2017/4/YEL.pdf. 